\title{
Implementasi Risk Management pada Pembiayaan Tabarok (Studi Kasus di BPRS Sarana Prima Mandiri Pamekasan)
}

\author{
Luthfiana Basyirah1), Iskandar Ritonga2), Mugiyati³) \\ 1), 2), 3) Universitas Islam Negeri Sunan Ampel Surabaya, Surabaya, Indonesia \\ Corresponding author: luthfianabasyirah31@gmail.com
}

\begin{abstract}
:
Tabarok Financing (Without Collateral and Barokah) is one of the products distributed by the Sharia People's Financing Bank SPM Pamekasan to the public by implementing mudārabah and unsecured contracts in carrying out MSME activities. Since the case of Covid-19 (Corona Virus Disease-19) which is increasingly widespread in Indonesia, the social and economic conditions of the community have been paralyzed. It is undeniable that this will be very influential and cause several problems, especially in various social and economic activities. This will also affect Islamic banking activities, including BPRS SPM Pamekasan which will be faced with several risks with different levels of complexity, these will continue to coexist with business activities. Thus, an institution needs to implement risk management with the aim of preventing financing risks that may occur in the future. The purpose of this study is to determine the implementation of risk management on Unsecured and Barokah financing at BPRS SPM Pamekasan by using a qualitative approach and the type of case study research. The results of the study stated that the implementation of risk management on Tabarok financing at BPRS SPM used 5 (five) risk management processes, that is risk identification, risk assessment, risk monitoring, risk control, and risk saving.
\end{abstract}

\section{Keywords: Risk management, Tabarok financing}

\begin{abstract}
Abstrak:
Pembiayaan Tabarok (Tanpa Agunan dan Barokah) merupakan salah satu produk yang disalurkan oleh Bank Pembiayaan Rakyat Syariah SPM Pamekasan kepada masyarakat dengan menerapkan akad mudārabah dan tanpa agunan dalam melaksanakan aktivitas UMKM. Sejak terjadi kasus Covid-19 (Corona Virus Disease-19) yang semakin meluas di Indonesia menyebabkan lumpuhnya kondisi sosial dan ekonomi masyarakat. Tidak bisa dipungkiri bahwa hal tersebut akan sangat berpengaruh dan menyebabkan beberapa permasalahan khususnya dalam berbagai kegiatan sosial dan ekonomi. Hal tersebut juga akan berpengaruh terhadap kegiatan Perbankan Shariah, termasuk BPRS SPM Pamekasan yang akan dihadapkan dengan beberapa risiko dengan tingkatan kompleksitas yang berbedabeda, hal tersebut akan terus berdampingan dengan kegiatan bisnis. Dengan demikian, suatu lembaga perlu melakukan implementasi manajemen risiko dengan tujuan untuk mencegah adanya risiko pembiayaan yang kemungkinan terjadi di kemudian hari. Tujuan dalam penelitian ini untuk mengetahui implementasi risk management pada pembiayaan Tanpa Agunan dan Barokah di BPRS SPM Pamekasan dengan menggunakan pendekatan kualitatif dan jenis penelitian studi kasus. Hasil penelitian menyatakan bahwa, implementasi risk management pada pembiayaan Tabarok di BPRS SPM Pamekasan menggunakan 5 (lima) proses manajemen risiko, yaitu identifikasi risiko, pengukuran risiko, monitoring risiko, pengendalian risiko, dan penyelamatan risiko.
\end{abstract}

Kata Kunci: Risk management, pembiayaan Tabarok 


\section{PENDAHULUAN}

Perbankan shariah merupakan seluruh kegiatan yang berhubungan dengan Bank Shariah dan Unit Usaha Shariah, mencakup segala kelembagaan kegiatan usaha, serta cara dan proses dalam melakukan kegiatan usahanya, hal ini tercatat dalam Undang-Undang Nomor 21 Tahun 2008. Sedangkan, bank yang melaksanakan seluruh kegiatan usahanya berdasarkan prinsip shariah disebut Bank Shariah. Berdasarkan jenisnya Bank Shariah terdiri dari Bank Umum Shariah yang disingkat menjadi (BUS) dan Bank Pembiayaan Rakyat Shariah yang disingkat menjadi (BPRS). ${ }^{1}$ Bank Pembiayaan Rakyat Shariah (BPRS) merupakan bank yang pelaksanakan kegiatan usahanya berdasarkan prinsip shariah dan dalam kegiatannya tidak memberikan jasa dalam lalu lintas pembayaran. ${ }^{2}$ Pada dasarnya, kegiatan Bank Pembiayaan Rakyat Shariah (BPRS) secara garis besar dapat dibagi menjadi dua fungsi utama, yaitu: penghimpunan dana dari masyarakat dan penyaluran dana kepada masyarakat yang membutuhkan. ${ }^{3}$

Dalam lima tahun terakhir hingga 2018 bank pembiayaan rakyat shariah (BPRS) mengalami kenaikan yang signifikan. Namun, beberapa kurun waktu ini tidak mengalami peningkatan yang signifikan seperti kurun waktu sebelumnya, tetapi jika dilihat dari sisi pembiayaan yang disalurkan kepada masyarakat sebagai pihak ketiga selalu mengalami peningkatan. Berdasarkan data Statistik Perbankan Shariah4, BPRS menyalurkan pembiayaan pada Juni 2020 mencapai Rp. 10,503 Triliyun yaitu meningkat sebesar 20\% dari penyaluran pembiayaan periode Juni 2019 yaitu sebesar Rp. 9,726 Triliyun. Sejak terjadi kasus Covid-19 (Corona Virus Disease- 19) yang semakin meluas di Indonesia menyebabkan lumpuhnya kondisi sosial dan ekonomi masyarakat. Tidak bisa dipungkiri bahwa hal tersebut akan sangat berpengaruh dan menyebabkan beberapa permasalahan khususnya dalam berbagai kegiatan sosial dan ekonomi. Hal tersebut juga akan berpengaruh terhadap kegiatan Perbankan Shariah, termasuk Bank Pembiayaan Rakyat Shariah (BPRS). ${ }^{5}$ Hal ini dapat dilihat dari grafik perkembangan rasio FDR, NPF, dan Profitabilitas dari Bank Pembiayaan Rakyat Shariah (BPRS) di Indonesia Tahun 2020.

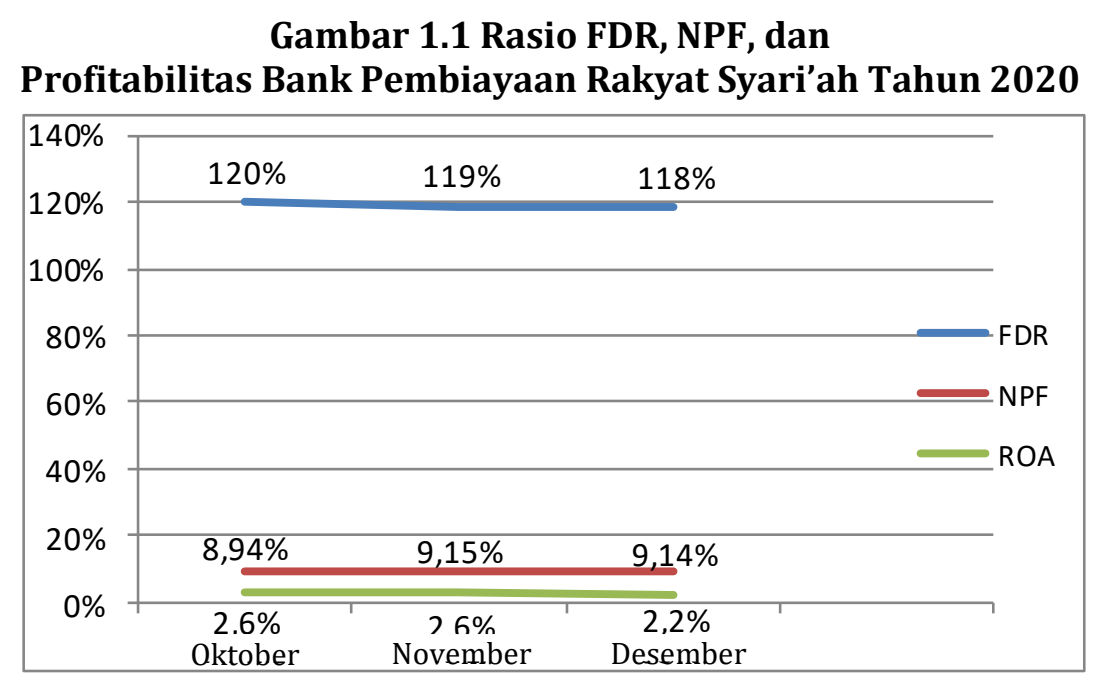

Sumber: ojk.go.id (data diolah) ${ }^{1}$

\footnotetext{
${ }^{1}$ Irham Fahmi, Manajemen Perbankan: Konvensional dan Syariah (Jakarta: Mitra Wacana Media, 2015), 26.

2 Adrian Sutedi, Perbankan Syariah Tinjauan dan Beberapa Segi Hukum (Bogor: Ghalia Indonesia, 2009), 50.

3 Ismail, Perbankan Syariah (Jakarta: Kencana, 2011), 54.

4 Otoritas Jasa Keuangan (OJK). Statistik Perbankan Syariah, Juni 2020. Departemen Perizinan dan Informasi Perbankan, 88.

${ }^{5}$ Diakses dari https://puspensos.kemsos.go.id , pada tanggal 27 Agustus 2020 pukul 12.10.
} 
Berdasarkan grafik di atas rasio pembiayaan yang disalurkan oleh BPRS terhadap total DPK mengalami penurunan dalam kurun waktu tiga bulan dari bulan Oktober, November, dan Desember 2020. Penyaluran jumlah pembiayaan yang semakin meningkat, tetapi rasio (Non Performing Financing), FDR (Financing to Deposit Ratio), dan ROA (Return on Asset) semakin menurun. Bahkan untuk periode Juni 2020, rasio NPF mencapai 9,14\%, FDR $118 \%$, dan ROA 2,2\%.

Saat ini dengan didukung oleh kondisi lingkungan eksternal dan internal bank pembiayaan rakyat shariah (BPRS) sebagai lembaga intermediasi mengalami peningkatan yang signifikan. Sehingga tidak dapat dipungkiri BPRS akan terus dihadapkan dengan beberapa risiko dengan tingkatan kompleksitas yang berbeda-beda, hal tersebut akan terus berdampingan dengan kegiatan bisnis. Dalam dunia perbankan, risiko dianggap sebagai suatu kesalahan potensial, berupa kejadian yang dapat diantisipasi (anticipated) maupun yang tidak dapat diantisipasi (un-anticipated) yang akan menimbulkan dampak negatif pada laporan keuangan terkait dengan pendapatan dan modal perbankan bank. ${ }^{6}$ Suatu perbankan harus mampu mengelola dan mengendalikan risiko-risiko yang terjadi karena hal tersebut tidak dapat dihindari. Sehingga dalam mengantisipasi risiko yang terjadi di masa depan, maka harus ada penerapan suatu manajemen dalam suatu bank. Manajemen merupakan proses pengendalian, penanganan, atau pengelolaan. ${ }^{7}$ Berdasarkan defisini yang berbeda, manajemen merupakan salah satu sumber daya yang digunakan secara efektif dalam mencapai suatu tujuan. ${ }^{8}$ Pada umumnya sebagai lembaga perbankan, mengharuskan bank pembiayaan rakyat shariah untuk melakukan beberapa prosedur dan metode yang dapat digunakan dalam melaksanakan pengidentifikasian, pengukuran, pemantauan, dan pengendalian risiko. ${ }^{9} \mathrm{Ni}$ Made Indah Purnama Dewi dkk, dalam penelitiannya memaparkan bahwa manajemen risiko adalah suatu proses manajemen yang digunakan untuk mengakomodasikan kemungkinan kegagalan dari suatu transaksi karena bersifat terarah dan proaktif. ${ }^{10}$

BPRS SPM merupakan salah satu bank pembiayaan rakyat shariah yang ada di Indonesia. BPRS SPM secara resmi beroperasi pada tanggal 1 Juli 2008 berdasarkan Keputusan Gubernur Bank Indonesia Nomor. 10/41/KEP. GBI/2008. BPRS SPM di Pamekasan lebih dikenal dengan Bank Shariah Sarana Prima Mandiri memiliki slogan "Bershariah Menuju Berkah", dengan tujuan agar produk-produk yang diberikan dalam Bank Shariah SPM dapat menyalurkan barokah berdasarkan shariah. Keberadaan Bank Pembiayaan Rakyat Shariah (BPRS) di pulau Madura yang dianggap bernuansa religi sangat diharapkan dapat memenuhi kebutuhan masyarakat Madura khusus Pamekasan dalam melakukan transaksi sesuai dengan shariah Islam.11

BPRS SPM memiliki usaha sendiri dalam memperoleh nasabahnya dan berdasarkan pada peraturan Otoritas Jasa Keuangan (OJK), yaitu dengan menciptakan produk baru yang diprioritaskan untuk pengusaha mikro atau penguasaha mikro kecil menengah dan perputaran bisnisnya dalam satu hari, hal ini bertujuan untuk membantu pengembangan

\footnotetext{
${ }^{6}$ Adiwarman A. Karim, Bank Islam: Analisis Fiqih dan Keuangan (Jakarta: Rajawali Pers, 2011), 255.

${ }^{7}$ Ismail Nawawi, Manajemen Perbankan Syariah, (Jakarta: CV Dwi Putra Pustaka Jaya, 2014), 224.

8 Jureid, "Manajemen Risiko Bank Islam (Penanganan Pembiayaan Bermasalah dalam Produk Pembiayaan pada PT Bank Muamalat Cabang Pembantu Panyabungan)", Jurnal Analytica Islamica, Vol. 5, No. 1, 2016, 86.

9 Masyhud Ali, Manajemen Risiko: Strategi Perbankan dan Dunia Usaha Menghadapi Tantangan Globalisasi Bisnis (Jakarta: PT RajaGrafindo Persada, 2006), 368.

${ }^{10}$ Ni Made Indah Purnama Dewi dan Ida Bagus Panji Sedana, "Efektivitas Manajemen Risiko dalam Mengendalikan Risiko Kredit di PT Bank Rakyat Indonesia", E-Jurnal Manajemen Unud, Vol. 6, No. 8, $2014,4299$.

${ }^{11}$ Diakses dari www.bprs-spm.com, pada tanggal 30 Agustus 2020 pukul 22.30.
} 
bisnis yang dilakukan oleh pengusaha tersebut. Produk tersebut berupa produk pembiayaan yang dikenal sebagai pembiayaan ${ }^{12}$ Tabarok (Tanpa Agunan dan Barokah).

Tabarok adalah pembiayaan yang disalurkan untuk masyarakat yang mempunyai usaha mikro, kecil dan menengah dengan perputaran modal bisnisnya dalam satu hari, dengan tujuan untuk membantu pengembangan usaha yang dimiliki oleh para pengusaha mikro. BPRS SPM Pamekasan mulai menyalurkan pembiayaan Tabarok pada bulan Mei 2017. Secara teknis, pembiayaan Tabarok (Tanpa Agunan dan Barokah) merupakan salah satu pembiayaan yang disalurkan kepada masyarakat dengan menerapkan akad muḍārabah dan tanpa agunan dalam melaksanakan aktivitas UMKM. Dalam hal ini pihak BPRS SPM membantu memenuhi seluruh dana bisnis yang dibutuhkan oleh nasabah tetapi tidak dengan memberikan pinjaman berupa uang, melainkan menjalankan hubungan partnership dengan nasabah, dimana yang menjadi penyandang dana (shahibul maal) adalah pihak bank dan yang menjalankan usahanya (muḍ̄rib) adalah nasabah.13

Pembiayaan Tabarok memiliki karakter yang menjadi keunggulan, yaitu prosedur dari awal pengajuan hingga pencairan pembiayaannya juga mudah dan cepat, serta dapat cair di hari yang sama, selama nasabah tersebut telah melengkapi berkas-berkas administrasi. Dalam penyaluran pembiayaan Tabarok juga tidak dibebankan biaya, sehingga sangat menguntungkan bagi nasabah dan nasabah dapat mendapatkan jumlah pinjaman yang disepakati dengan utuh. Plafond pinjaman pokok yang diberikan dalam pembiayaan Tabarok sebesar Rp. 1.000.000,- s/d Rp. 10.000.000,- dengan jangka waktu pembayaran angsuran maksimal 6 bulan. Secara teknis pembiayaan Tabarok ini adalah pembiayaan dengan menggunakan akad muḍārabah, maka keuntungan akan dibagi hasil antara pihak bank dan nasabah. Pihak bank memperoleh $20 \%$, dan nasabah memperoleh $80 \%$ dari tabungan harian nasabah setiap bulannya. Tetapi sebelum dilakukan bagi hasil, terlebih dahulu uang tersebut dipotong sebesar 2,5\% yang digunakan untuk infaq dan shadaqah. ${ }^{14}$

Berikut ini adalah data BPRS SPM (SPM) Pamekasan terkait jumlah pembiayaan Tabarok di Triwulan II Juni 2020, yaitu sebagai berikut:

\section{Gambar 1.2 Jumlah Pembiayaan Tabarok Triwulan II Juni 2020}

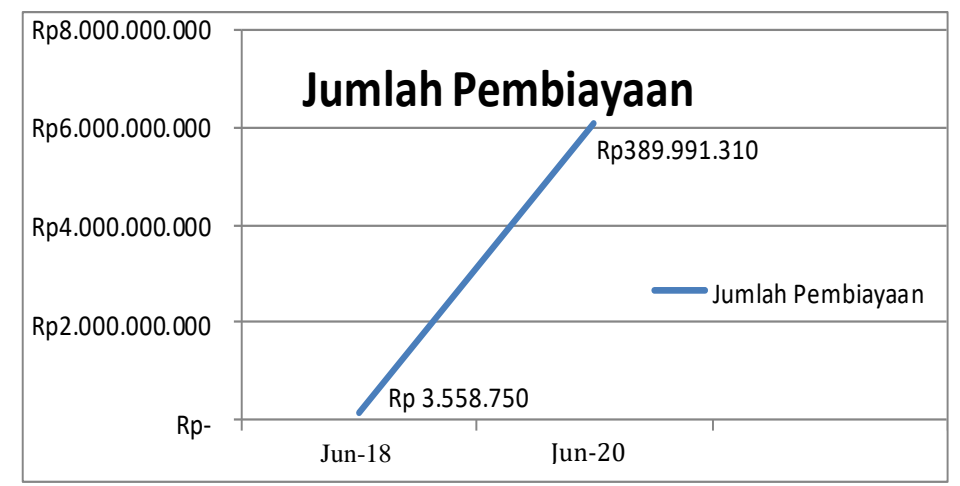

Sumber: Aplikasi Laporan Keuangan BPRS SPM (data diolah)

\footnotetext{
12 Pembiayaan atau financing yaitu pendanaan yang diberikan oleh suatu pihak kepada pihak lain untuk mendukung investasi yang telah direncanakan, baik dilakukan sendiri maupun lembaga.

13 Edi Susilo, “Analisis Perbandingn Penerapan Manajemen Risiko Pembiayaan Lembaga Keuangan Mikro Syariah Studi Kasus di BMT Beringharjo Yogyakarta dan BPRS Madina Mandiri Sejahtera Yogyakarta.", Jurnal Ekonomi Bisnis \& Kewirausahaan, Vol. 4, No. 2, (Agustus, 2014), 23.

${ }^{14}$ BPRS SPM, Brosur Pembiayaan Tabarok, Pamekasan, 2020.
} 
Seperti tampak pada grafik di atas, seiring dengan meningkatnya jumlah pembiayaan Tabarok yang disalurkan, risiko yang dihadapi BPRS SPM pun akan meningkat. Risiko yang dihadapi BPRS SPM karena kesalahan dalam pengelolaan risiko pembiayaan ${ }^{15}$ dapat berakibat fatal pada peningkatan NPF (Non Performing Financing) ${ }^{16}$.

\section{Gambar 1.3 Rasio NPF dan Profitabilitas BPRS SPM Pamekasan}

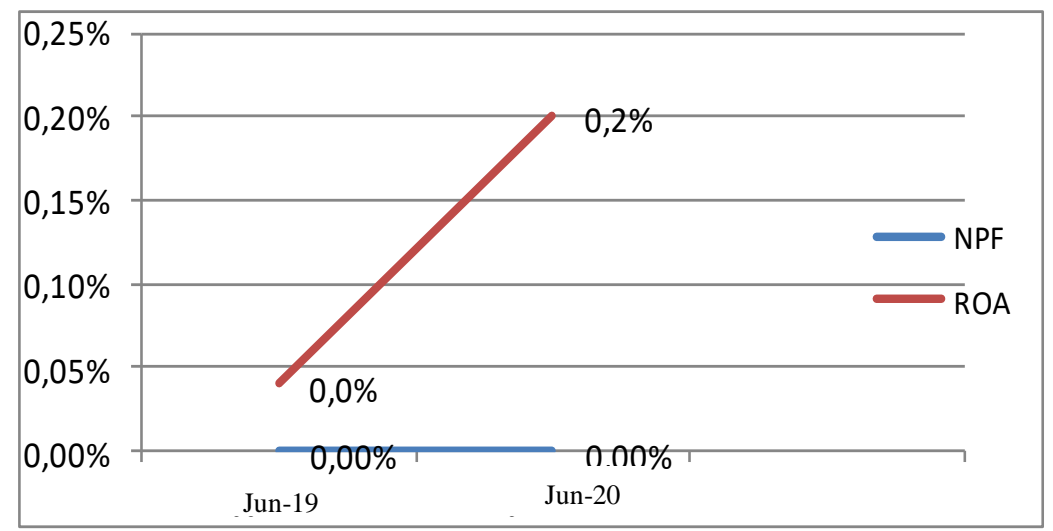

Sumber: Aplikasi Laporan Keuangan BPRS SPM (data diolah)

Rasio pembiayaan bank pembiayaan rakyat syariah terhadap total DPK yang terhimpun selalu meningkat hanya dalam kurun waktu satu tahun, yaitu dari bulan Juni 2019 hingga bulan Juni 2020 yang dapat dilihat dalam diagram garis di atas. Berdasarkan diagram garis di atas, seiring dengan peningkatan jumlah pembiayaan yang disalurkan, rasio NPF (Non Performing Financing) akan mengalami peningkatan. Tetapi, khusus pembiayaan Tabarok rasio NPF (Non Performing Financing) dari bulan Juni 2019 hingga bulan Juni 2020 tidak mengalami peningkatan, yaitu tetap sebesar $0 \%$, dan profitabilitas yang dihitung menggunakan rasio ROA (Return of Asset) terus meningkat setiap bulannya menjadi $0,2 \% \mathrm{di}$ bulan Juni 2020.

Besarnya risiko yang terjadi pada suatu perusahaan atau perbankan, akan sangat berpengaruh pada profitabilitas di perusahaan atau perbankan tersebut. Seperti dijelaskan oleh Ni Wayan Wita Capriani dan I Made Dana dalam penelitiannya, profitabilitas merupakan salah satu rasio untuk mengetahui kemampuan perusahaan dalam mendapatkan laba yang berhubungan dengan penjualan, total assets, dan equity. Sehingga dapat disimpulkan bahwa profitabilitas yang tinggi dapat menunjukkan kemampuan perusahaan dalam memenuhi kewajibannya, selain itu perusahaan juga akan memperoleh keuntungan ketika persentase profitabilitasnya meningkat. Profitabilitas dapat diukur dengan melakukan penghitungan

\footnotetext{
15 Risiko pembiayaan adalah risiko yang terjadi karena kegagalan debitur, yang menyebabkan tidak terpenuhinya kewajiban untuk membayar hutang (pembiayaan)

${ }^{16}$ NPF (Non Performing Financing) atau pembiayaan bermasalah adalah kondisi ketika nasabah tidak dapat melakukan pembayaran sebagian atau seluruh kewajiban angsuran pembiayaannya kepada bank sesuai dengan kesepakatan jangka waktu yang telah disepakati dalam akad pembiayaan. Dengan begitu, penyebab terjadinya pembiayaan bermasalah (NPF) karena nasabah tidak dapat melakukan pengembalian pinjaman sesuai dengan jangka waktu yang telah disepakati. Sehingga hal tersebut bisa menurunkan kualitas pembiayaan dan pihak bank akan mengalami kerugian secara potensial.
} 
pada akun yang terdapat dalam laporan keuangan dengan menggunakan rumus rasio keuangan. ${ }^{17}$

Dengan demikian, implementasi manajemen risiko pembiayaan dalam suatu lembaga perlu dilaksanakan sebagai salah satu bentuk antisipasi terhadap risiko pembiayaan yang kemungkinan terjadi di kemudian hari. Esensi implementasi risk management merupakan kelengkapan dari proses dan metodologi dalam melakukan pengelolaan terhadap risiko, sehingga segala aktivitas perbankan tetap dapat dikendalikan dalam batasan yang normal dan memberikan keuntungan terhadap pihak perbankan, sehingga perlu adanya dukungan dalam melakukan pengelolaan dari implementasi manajemen risiko. Adapun empat langkah yang dilakukan oleh perbankan dalam melakukan pengelolaan manajemen risiko, yaitu: pengidentifikasian, pengukuran, pemantauan, dan pengendalian. ${ }^{18}$ Pelaksanaan risk management sangat berguna dalam meningkatkan shareholder value, menciptakan infrastruktur risk management yang kokoh sehingga daya saing bank juga akan mengalami peningkatan. ${ }^{19}$

\section{METODE PENELITIAN}

Pada penelitian yang bertujuan untuk mengetahui risk management pada pembiayaan Tabarok di BPRS SPM Pamekasan ini, peneliti menggunakan pendekatan kualitatif dengan jenis penelitian studi kasus. Jenis penelitian studi kasus (case study) dapat didefinisikan sebagai salah satu strategi peneliti dalam melakukan penyelidikan secara teliti dalam suatu program, kejadian, kegiatan, proses, ataupun sekelompok individu. ${ }^{20}$ Lokasi dalam penelitian ini adalah BPRS SPM Kantor Pusat Pamekasan yang terletak di Jl. KH. Agus Salim No. 20, Kelurahan Barurambat Kota, Kecamatan Pamekasan, Kabupaten Pamekasan. Sumber data yang digunakan dalam penelitian ini yaitu sumber data primer dan sekunder. Teknik pengumpulan data diperoleh dari observasi, wawacara, dan dokumentasi. Kemudian data yang telah dikumpulkan dilakukan analisis dengan cara mereduksi data, men-display data, dan menarik kesimpulan. Sedangkan untuk teknik validasi data dalam penelitian ini menggunakan triangulasi sumber data.

\section{HASIL DAN PEMBAHASAN}

Manajemen adalah proses merencanakan, mengelompokkan, mengarahkan, dan mengawasi segala kegiatan para anggota organisasi sebagai salah satu cara pencapaian tujuan yang sudah disepakati bersama. ${ }^{21}$ Setiap kali melakukan pencapaian tujuan, lembaga keuangan shariah sangat membutuhkan adanya suatu manajemen, karena dalam pencapaian tujuan tersebut tidaklah mudah dan tidak dapat dipungkiri bahwa suatu perusahaan akan dihadapkan dengan berbagai jenis risiko, salah satunya risiko pembiayaan yang disebabkan oleh keterlambatan dalam pembayaran angsuran pembiayaan. Manajemen risiko dalam Islam bertujuan untuk menjauhi sifat boros. Al- Qur'an menjelaskan hal tersebut dalam surah ArRa'ad: 11, sebagai berikut:

\footnotetext{
17 Ni Wayan Wita Capriani dan I Made Dana, "Pengaruh Risiko Kredit, Risiko Operasional, Risiko Likuiditas Terhadap Profitabilitas BPR di Kota Denpasar.", E-Jurnal Manajemen Unud, Vol. 5, No. 3, 2016, 1494.

${ }^{18}$ Muhammad, Manajemen Pembiayaan Bank Syari'ah (Yogyakarta: UPP AMP YKPN, 2006), 17.

${ }^{19}$ Rudi, "Manajemen Risiko Bank Pengkreditan Rakyat dan Pengaruhnya Terhadap Non Performing Loan (Study Kasus BPR di Kota Tangerang Selatan).", dalam Jurnal Sekuritas Manajemen Keuangan, Vol. 1, No. 1, (September, 2017), 61.

${ }^{20}$ John W. Creswell, Research Design: Pendekatan Kualitatif, Kuantitatif, dan Mixed (Yogyakarta: Pustaka Pelajar, 2017), 20.

${ }^{21}$ Sukamdiyo, Manajemen Koperasi (Jakarta: Erlangga, 1996), 1.
} 


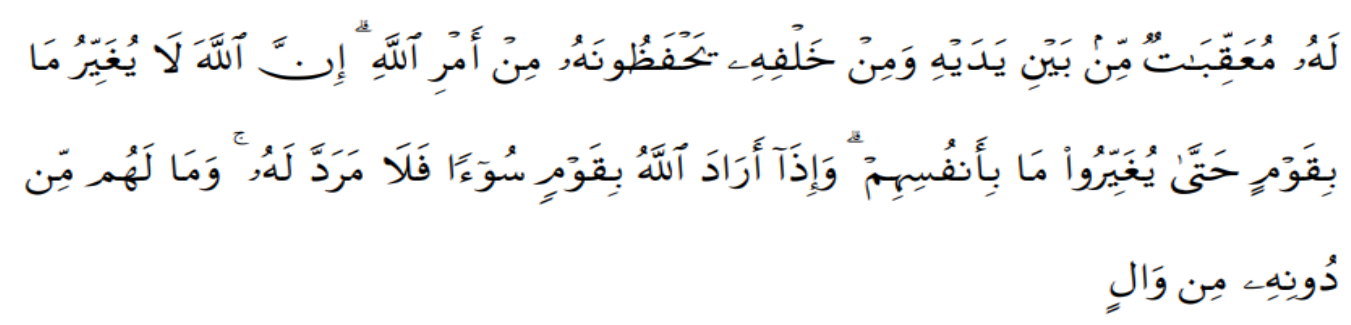

"Bagi manusia ada malaikat-malaikat yang selalu meng „uvinya secara bergiliran, di muka dan di belakangnya, mereka menjaganya atas perintah Allah. Sesungguhnya Allah merubah keadaan yang ada pada diri mereka sendiri. Dan apabila Allah menghendaki keburukan terhadap sesuatu kaum, maka tidak ada yang dapat menolaknya, dan sekali-kali tidak ada pelindung bagi mereka selain Dia”. (QS. ArRa'ad: 11$)^{22}$

Berdasarkan ayat di atas menjelaskan bahwa jika seorang hamba tidak memiliki kemauan untuk mengubah pandangan hidupnya, maka keadaannya juga akan sama tidak ada perubahan dalam cara pengelolaan harta dan usaha yang dimilikinya. Hal tersebut sama dengan manajemen risiko dalam Islam yang mengingatkan agar selalu berhemat dalam mengelola harta yang dimiliki dengan memperhatikan kemungkinan kondisi yang terjadi di masa depan. Sehingga menabung atau berinvestasi juga diperlukan sebagai solusi untuk memudahkan dalam menghadapi suatu risiko.

BPRS SPM merupakan salah satu lembaga perbankan yang melaksanakan prinsipprinsip shariah dalam melakukan transaksi penghimpunan dan penyaluran dana. BPRS SPM mempunyai motto "Bershariah Menuju Berkah" yang bertujuan agar produk yang disalurkan bisa memberikan berkah kepada nasabah dan karyawannya. BPRS saat ini semakin mengembangkan dan memperluas jangkauannya dengan menciptakan beberapa product yang sangat membantu masyarakat, salah satunya BPRS SPM. BPRS SPM memiliki produk pembiayaan unggulan yang banyak diminati masyarakat yaitu pembiayaan Tabarok, yang biasanya dikenal dengan pembiayaan tanpa agunan dan barokah. Dengan adanya pembiayaan Tabarok diharapkan dapat membantu pengusaha kecil mikro dan menengah (UMKM), terutama pedagang yang terjerat hutang kepada rentenir.

Dalam dunia perbankan pendanaan yang diserahkan oleh salah satu pihak kepada pihak lain yang memerlukan dana untuk mendukung investasi yang telah direncanakan baik yang dilakukan sendiri maupun lembaga disebut pembiayaan atau financing. ${ }^{23}$ BPRS SPM memberikan pembiayaan kepada nasabah yang memiliki usaha mikro kecil menengah (UMKM) dan usahanya sudah berjalan minimal selama 6 bulan, dengan menggunakan akad muḍārabah atau sistem bagi hasil, yaitu pembiayaan Tabarok Muḍārabah adalah akad kerjasama antara dua pihak atau lebih, dalam hal ini bank membantu memenuhi seluruh dana bisnis yang dibutuhkan oleh nasabah tetapi tidak dengan memberikan pinjaman berupa uang, melainkan menjalankan hubungan partnership dengan nasabah, dimana yang menjadi penyandang dana (shahibul maal) adalah pihak bank dan yang menjalankan usahanya (muḍārib) adalah nasabah. ${ }^{24}$ BPRS SPM Pamekasan dalam hal ini akan memberikan pertanggungjawaban ketika omset penjualan dari bisnis yang dijalankan oleh nasabah semakin menurun, kecuali jika kesalahan yang dilakukan secara sengaja oleh nasabah. Pembiayaan mud̄orrabah prinsipnya disalurkan tanpa harus menyerahkan agunan, tetapi agar nasabah tidak melakukan kesalahan yang dilakukan secara sengaja, sehingga pihak bank

\footnotetext{
22 Departemen Agama RI, Al- Qur'an dan Terjemahan Tajwid, 135.

23 Binti Nur Asiyah, Manajemen Pembiayaan Bank Syariah (Yogyakarta: Kalimedia, 2015), 2.

${ }^{24}$ Edi Susilo, “Analisis Perbandingn Penerapan Manajemen Risiko,23.
} 
berhak meminta agunan kepada nasabah. ${ }^{25} \mathrm{Hal}$ ini sesuai dengan pembiayaan Tabarok yang ada di BPRS SPM yang tidak perlu menyerahkan agunan dalam pembiayaan Tabarok dan tidak ada potongan biaya apapun, tetapi terdapat potongan dana bagi nasabah yang telah tercover asuransi.

Ciri utama dari pembiayaan Tabarok ${ }^{26}$, selain tanpa jaminan juga proses pencairan yang cepat, bahkan dalam hitungan jam selama syarat-syarat administratif dinilai lengkap. Pencairan pembiayaan Tabarok tersebut juga tidak dibebani dengan biaya apapun sehingga nasabah dapat menerima utuh sebesar jumlah pinjaman yang disetujui. Plafond pinjaman pokok yang diberikan dalam pembiayaan Tabarok sebesar Rp. 1.000.000,- s/d Rp. 10.000.000,- dengan jangka waktu pembayaran angsuran maksimal 6 bulan.

Implementasi risk management pada pembiayaan Tabarok di BPRS SPM Pamekasan ini merupakan salah satu proses untuk meminimalisir kemungkinan terjadinya risiko yang muncul diakibatkan karena nasabah tidak dapat memenuhi kewajibannya untuk membayar angsuran sampai lunas. Penanggung jawab manajemen risiko ini adalah Sie Kepatuhan dan Manajemen Risiko, serta Direktur Utama dan Direktur BPRS SPM. Selain itu juga terdapat karyawan khusus pembiayaan Tabarok yang terlibat dalam proses manajemen risiko dan pemberian keputusan dalam menyalurkan pembiayaan Tabarok yaitu Kasie pembiayaan Tabarok dan Account Officer.

Adapun proses implementasi dari karakter dalam risk management pada pembiayaan Tabarok di BPRS SPM yang dapat digunakan untuk meminimalisir terjadinya pembiayaan Tabarok bermasalah yaitu, dengan cara risk identification, risk assessment, risk monitoring, risk control dan risk saving.

\section{A. Risk Identification}

Identifikasi risiko merupakan suatu kegiatan mengumpulkan seluruh informasi yang berkaitan dengan usaha calon nasabah, kemudian melakukan analisis untuk menemukan eksposur risiko yang dapat menyebabkan terjadinya kerugian. ${ }^{27}$ Proses identifikasi risiko di BPRS SPM ini dilakukan oleh Account Officer. Account Officer analisis target pasar dan mengumpulkan informasi-informasi yang berkaitan dengan calon nasabah. Analisis target pasar dilakukan untuk memudahkan dalam mengamati kriteria usaha calon nasabah, yaitu usaha tetap yang sudah berjalan minimal selama enam bulan, bukan usaha musiman saja.

Proses identifikasi risiko yang dilakukan BPRS SPM Pamekasan saat bulan Ramadhan, yaitu dengan cara tidak melakukan penyaluran pembiayaan Tabarok kepada pengusaha mikro, kecil, dan menengah. Artinya, BPRS SPM Pamekasan, tidak menerima permohonan pengajuan pembiayaan Tabarok oleh nasabah baru selama bulan Ramadhan, karena dikhawatirkan pengusaha musiman yang melakukan pengajuan pembiayaan Tabarok. Pembiayaan Tabarok hanya berlaku bagi calon nasabah yang memiliki usaha yang berjalan minimal selama enam bulan dan sudah mempunyai lapak atau lokasi yang tetap.

Setelah melihat target pasar, selanjutnya Account Officer harus mengumpulkan informasi-informasi calon nasabah, dengan cara melakukan wawancara mengenai usaha yang sedang dijalankan oleh calon nasabah. Maka dari itu Account Officer harus melakukan analisis pembiayaan $4 \mathrm{C}+1 \mathrm{~S}$, yaitu character, capacity, capital, condition of economy dan shariah. Pentingnya melakukan analisis pembiayaan $4 \mathrm{C}+1 \mathrm{~S}$, karena memudahkan Account Officer untuk mengetahui karakter, kemampuan modalnya, pendapatannya, kemampuan untuk

${ }^{25}$ Fatwa Dewan Syari'ah Nasional MUI, No: 07/DSN-MUI/IV/2000 tentang Pembiayaan Mudharabah (Qiradh).

${ }^{26}$ Ada sisi edukasi dalam pelaksanaan pembiayaan Tabarok ini, dimana nasabah diharuskan untuk menyisihkan sebagian dari penghasilan yang didapat dalam sehari untuk ditabung, sehingga dengan demikian masyarakat akan terbiasa untuk menabung dan menghilangkan kebiasaan untuk mengkomsumsi penghasilannya sebagaimana sering terjadi selama ini.

${ }^{27}$ Mamduh M. Hanafi, Manajemen Risiko (Yogyakarta: UPP STIM YKPN, 2016), 10. 
membayar angsuran pembiayaan, prospek usaha di masa yang akan datang, kondisi ekonomi calon nasabah, dan melihat kemungkinan calon nasabah juga memiliki profesi lainnya.

\section{Character}

Dalam menganalisis karakter nasabah pembiayaan akan dilihat tingkah lakunya dalam kesehariannya, baik disekitar lembaga, tempat tinggal dan lokasi usahanya, karena untuk mengetahui karakter individu sangatlah sulit, bisa jadi sekarang berkata jujur, tetapi di lain waktu bisa saja sewaktu-waktu tidak jujur, dengan begitu akan terlihat pada akhlak dan kejujuran nasabah pembiayaan Tabarok. Jika tingkah lakunya sudah terlihat baik, maka BPRS SPM tidak akan merasa khawatir karena tingkah laku yang baik adalah gambaran kepribadian nasabah tersebut. Dengan melakukan penilaian tersebut, pihak BPRS SPM Pamekasan dapat menentukan layak atau tidaknya mendapatkan pembiayaan Tabarok.

\section{Capacity}

Capacity merupakan cara untuk menganalisis pembiayaan dengan melakukan penilaian secara subyektif tentang kemampuan calon debitur dalam memenuhi kewajibannya sesuai jangka waktu pembiayaan. ${ }^{28}$ Untuk menilai kemampuan dalam membayar angsuran pembiayaan nantinya, pihak BPRS SPM harus benar-benar mengetahui banyaknya sumber pendapatan nasabah pembiayaan, sumber pendapatan nasabah dilihat apakah nasabah tersebut memiliki usaha-usaha yang dapat menghasilkan uang atau hanya mengandalkan slip gaji saja. Jika nasabah tersebut memiliki usaha dan berjalan dengan baik serta dapat menghasilkan uang maka dapat disimpulkan nasabah tersebut memiliki kemampuan untuk mengembalikan dananya ke BPRS SPM Pamekasan.

\section{Capital}

Capital merupakan analisis pembiayaan dengan cara melihat kemampuan modal yang dimiliki oleh calon nasabah pembiayaan Tabarok, dan diukur dengan melihat posisi BPRS SPM secara keseluruhan yang ditujukan oleh penekanan komposisi modalnya. ${ }^{29}$

Pihak bank wajib mengetahui modal usaha yang dimiliki oleh calon nasabah, karena hal tersebut dapat mempengaruhi pendapatan nasabah. Jika modal dan plafond pinjaman yang diajukan oleh calon nasabah jumlahnya besar, maka kemungkinan dalam memperoleh laba juga besar. Tetapi hal yang perlu diperhatikan, terkadang calon nasabah tidak dapat mengukur kemampuannya dalam jangka waktu yang panjang. Misalkan, salah satu calon nasabah yang memiliki usaha warung makan mengajukan pembiayaan Tabarok dengan plafond pinjaman sebesar Rp 3.500.000, berdasarkan analisa account officer dengan memberikan plafond pinjaman sebesar Rp $1.000 .000 \mathrm{~s} / \mathrm{d} \mathrm{Rp} 1.500 .000$ untuk modal tambahan usaha warung makannya bisa dikatakan cukup. Dalam hal ini, account officer wajib melakukan pengecekan pendapatan calon nasabah setiap harinya, sehingga dapat mengetahui perputaran modal calon nasabah tersebut cukup atau tidak. Ketika pihak BPRS SPM memberikan plafond pinjaman sesuai dengan yang diajukan oleh calon nasabah, mereka akan merasa terbebani dengan jumlah angsuran pembiayaan setiap harinya disaat omset penjualannya menurun. Maka dari itu BPRS SPM wajib mengetahui hal tersebut, sehingga dapat menyesuaikan dengan nasabah. Jika seiring berjalannya waktu nasabah warung makan tersebut dapat membayar angsuran pembiayaan dengan lancar, maka ketika nasabah memerlukan tambahan planfond pinjaman untuk mengembangkan usahanya, pihak BPRS SPM juga tidak akan segan untuk meningkatkan plafond

\footnotetext{
${ }^{28}$ Ismail, Manajemen Perbankan: Dari Teori Menuju Aplikasi (Jakarta: PrenadaMedia Group, 2016), 115.
}

${ }^{29}$ Kasmir, Dasar-Dasar Perbankan, (Jakarta: Rajawali Pers, 2014), 138. 
pinjamannya. Tetapi, apabila nasabah tersebut tidak membutuhkan tambahan plafond pinjamannya sebagai modal, kemungkinan plafond pinjaman yang diberikan tetap.

\section{Condition of Economy}

Condition of economy merupakan salah satu cara untuk melakukan analisis pembiayaan dengan melihat kondisi perekonomian calon nasabah secara umum. ${ }^{30}$ BPRS SPM harus melakukan analisis terhadap kondisi ekonomi dan kondisi sosial calon nasabah karena akan berpengaruh pada angsuran pembiayaan calon nasabah. Status calon nasabah juga harus diperhatikan, apakah nasabah tersebut sudah menikah atau belum, jika sudah maka perlu untuk menanyakan berapa jumlah anggota yang menjadi tanggungannya. Pentingnya melakukan analisis dan penyelidikan secara detail dalam rangka agar dapat meminimalisir kemungkinan terjadinya sesuatu yang tidak diinginkan dalam jangka waktu panjang. Misalnya, ketika salah satu nasabah pembiayaan Tabarok statusnya masih sepasang suami istri, tetapi saat pembiayaannya sudah berjalan dan suami istri tersebut bercerai yang menyebabkan kondisi usahanya terganggu, sehingga akan berpengaruh juga pada angsuran pembiayaannya. Dalam hal ini pihak BPRS SPM tetap mencarikan solusi terbaik agar angsuran pembiayaannya bisa berjalan dan tidak membebani nasabah. Salah satu solusi yang diberikan oleh pihak BPRS SPM yaitu dengan melibatkan orangtua nasabah untuk membantu penyelesaian angsuran pembiayaan, tetapi hanya mengembalikan pokok plafond pinjamannya saja.

\section{Shariah}

Penilaian ini dilakukan untuk menegaskan bahwa usaha yang akan dibiayai benar-benar usaha yang tidak melanggar shariah dengan fatwa DSN MUI, bahwa "pengelola tidak boleh menyalahi hukum shariah Islam dalam tindakannya yang berhubungan dengan muḍārabah." ${ }^{11}$ Sehingga, pembiayaan Tabarok harus menerapkan prinsip shariah, dengan cara memotong total angsuran pembiayaan nasabah sebesar $2.5 \%$ yang nantinya disalurkan untuk infaq dan shadaqah. Dana infaq dan shadaqah biasanya diberikan kepada masyarakat atau bahkan nasabah pembiayaan Tabarok yang dikategorikan sebagai kaum dhuafa. Penyaluran dana infaq dan shadaqah biasanya berupa kebutuhan pokok, sumbangan untuk anak yatim, untuk nasabah yang sedang mendapatkan musibah, dan terkadang dimanfaatkan untuk wisata religi bersama nasabah pembiayaan Tabarok. Selain itu, terdapat pendekatan agama yaitu tentang menjauhi bahaya riba, karena nasabah selalu ingatkan untuk menjalankan kewajibannya membayar hutang sebagai salah satu bentuk saling tolong menolong antara nasabah dan pihak BPRS SPM, sehingga terciptalah ikatan kekeluargaan sebagai rekan kerja.

Selain melakukan analisis pembiayaan $4 \mathrm{C}+1 \mathrm{~S}$, pihak BPRS SPM juga perlu melakukan analisis $7 \mathrm{P}$ yaitu personality, party, purpose, prospect, payment, protection, dan protection. Pertama, dalam melakukan analisis personality, account officer harus mengetahui perilaku calon nasabah tersebut. Misalkan sikap calon nasabah yang tidak jujur, maka akan sangat berpengaruh pada pembiayaan, selain itu calon nasabah mempunyai emosional yang berlebih, sehingga tidak dapat menahan emosinya ketika mengalami suatu masalah, hal tersebut juga sangat membahayakan proses pelaksanaan pembiayaan Tabarok.

Kedua, dalam proses analisis party, account officer harus mengklasifikasikan calon nasabah berdasarkan modal yang dimiliki dan personality, karena hal ini akan berpengaruh pada penyaluran plafond pembiayaan kepada calon nasabah. Ketiga, analisis purpose dilakukan agar mengetahui tujuan penggunaan pembiayaan Tabarok, karena pembiayaan

\footnotetext{
${ }^{30}$ Ismail, Manajemen Perbankan: Dari Teori Menuju Aplikasi, 116.

${ }^{31}$ Fatwa Dewan Syari'ah Nasional MUI, No: 07/DSN-MUI/IV/2000 tentang Pembiayaan Mudharabah (Qiradh).
} 
tersebut dikhususkan untuk kegiatan usaha yang produktif, tidak untuk kegiatan konsumtif. Tetapi hal ini bisa saja terjadi, jika nasabah yang mengajukan pembiayaan Tabarok untuk tambahan modal usahanya dan dana tersebut cair, nasabah tidak menggunakan dana pembiayaan Tabarok untuk melunasi hutangnya kepada rentenir. Ketika pembayaran angsuran pembiayaan mengalami kemacetan, maka akan menyulitkan nasabah sendiri karena tidak berkata jujur kepada pihak BPRS SPM. Berbeda lagi jika nasabah berkata jujur, maka pihak BPRS SPM juga tidak enggan untuk membantu penyelesaian masalahnya dan nasabah juga akan mendapatkan tambahan modal usaha. Keempat, analisis prospect digunakan untuk mengetahui usaha nasabah memiliki peningkatan omset dan berkembang atau tidak. Jika usaha nasabah tidak mengalami perkembangan dan peningkatan omset, maka akan berpengaruh terhadap payment nya. Selain itu, account officer harus memikirkan kemampuan payment nasabah untuk mengembalikan pembiayaan, jika plafond pinjaman sangat tinggi dan melebihi kapasitas kemampuan nasabah, dikhawatirkan usaha nasabah tersebut tidak terdapat perkembangan nantinya. Sedangkan, protection dilakukan dengan tujuan untuk melindungi pembiayaan yang diberikan oleh pihak BPRS SPM melalui sistem perlindungan atau penyelamatan pembiayaan, dengan cara men-cover pembiayaan calon nasabah.

Misalkan, pada saat AO melaksanakan survei ke salah satu calon nasabah, yaitu nasabah B yang melakukan pengajuan pembiayaan dengan plafond pinjaman sebesar Rp. 6.000.000. Nasabah B yang merupakan pedagang toko retail mengatakan bahwa ia mampu untuk melakukan pembayaran angsuran setiap harinya, karena hasil dari penjualannya sangat mencukupi untuk membayar Rp. 30.000/ hari. Pendapatan bersih yang diperoleh setiap harinya bisa sampai Rp. 650.000/ hari.

Dalam hal ini Account Officer harus mampu menilai karakter dari calon nasabah pembiayaan Tabarok dengan cara melakukan survey dan wawancara kepada calon nasabah untuk menggali informasi berkaitan dengan lokasi usaha, penghasilan dalam satu hari, pelanggan, tempat tinggal, dan kondisi ekonominya. Pada tahap ini pihak bank harus benarbenar berhati-hati dan bisa menganalisis secara mendalam, karena karakter manusia tidak dapat diprediksi. Bisa saja pada saat pihak bank melakukan survey, calon nasabah tersebut berkata jujur, tetapi bisa saja sewaktu-waktu calon nasabah tersebut juga tidak jujur. Oleh sebab itu, pihak bank menilai karakter nasabah pembiayaan Tabarok berdasarkan perilaku nasabah sehari-hari, dimana pihak bank akan menanyakan kepada orang-orang terdekat yang biasa datang ke tempat usaha yang dijalankan oleh calon nasabah tersebut. Selain itu, pihak bank khususnya bagian pembiayaan Tabarok juga melihat bagaimana perilaku nasabah dalam menyambut pihak bank ketika pihak bank mendatangi tempat usaha atau rumah nasabah tersebut.

\section{B. Risk Assessment}

Setelah melakukan proses identifikasi risiko, selanjutnya melakukan pengukuran terhadap risiko, yang bertujuan untuk menggali lebih dalam lagi informasi yang berhubungan dengan calon nasabah. ${ }^{32}$ Hal tersebut dilakukan agar pihak BPRS SPM Pamekasan dapat memprediksi risiko yang akan terjadi pada usaha calon nasabah tersebut, karena setiap usaha memiliki risiko yang berbeda. Misalnya pengukuran risiko berdasarkan kuantitasnya kepada calon nasabah yang mengajukan permohonan pembiayaan Tabarok dengan plafond pinjaman sebesar Rp. 1.500.000, tidak akan sama dengan calon nasabah yang plafond pinjamannya sebesar Rp. 9.000.000. Account officer tidak akan mungkin memberikan plafond pinjaman melebihi dari kemampuan dari calon nasabah, karena apabila account officer

\footnotetext{
32 Ismail, Manajemen Perbankan: Dari Teori Menuju Aplikasi, 117.
} 
memberikan pembiayaan di luar kemampuan nasabah, maka pihak BPRS SPM Pamekasan yang akan menanggung risikonya.

Sedangkan, pengukuran risiko berdasarkan kualitasnya dapat dilihat dari kemungkinan risiko yang akan terjadi.33 Dalam pengajuan pembiayaan Tabarok tidak terdapat BI checking serta penyalurannya tanpa harus menyerahkan agunan, maka dari itu pihak bank harus berhati-hati dan cermat dalam menentukan keputusan yang diambil dengan melihat karakter dan tingkah laku para calon nasabah, melakukan evaluasi plafond pengajuan pembiayaan yang harus disesuaikan dengan kemampuan nasabah, serta jangka dalam pengembalian angsuran pembiayaan.

\section{Risk Monitoring}

BPRS SPM tidak hanya mengetahui arus kas saja, namun juga melakukan monitoring usaha nasabah. Proses monitoring dilaksanakan ketika nasabah sudah menggunakan pembiayaan Tabarok. Monitoring risiko sangat dibutuhkan untuk melakukan pemantauan terhadap perkembangan usaha nasabah. ${ }^{34}$ Dalam hal ini account officer sangat berperan langsung dalam pemantauan pembayaran angsuran pembiayaan nasabah, karena bertujuan untuk mengetahui pembayaran angsuran pembiayaan Tabarok lancar atau tidak. Selain memantau dari laporan rekening nasabah, pemantuan secara langsung ke lokasi usaha nasabah sangat penting dilakukan untuk melihat prospek dan perkembangan usaha.

Apabila usaha yang dijalankan oleh nasabah mengalami perkembangan dan peningkatan pada omsetnya, maka pembayaran angsuran pembiayaannya pun juga bisa berjalan dengan lancar, selain itu nasabah juga dapat memperoleh bagi hasil rutin dari pembiayaan Tabarok setiap bulan. Namun sebaliknya, jika usaha yang dijalankan oleh nasabah mengalami penurunan omset, maka pembayaran angsuran pembiayaan nasabah juga akan terganggu, begitu pula dengan bagi hasilnya. Sehingga pihak BPRS SPM perlu mencari informasi berkaitan dengan penurunan omset penjualannya, setelah itu memberikan solusi agar usaha nasabah bisa bertahan, mengalami perkembangan dan peningkatan omset penjualan seperti semula.

Nasabah A, salah satu nasabah pembiayaan Tabarok yang memiliki warung makan dan kopi di sekitar Pasar 17 Agustus Pamekasan menggunakan dana pembiayaan Tabarok yang berlangsung selama kurang lebih 8 bulan sebanyak dua kali. Pengajuan pembiayaan Tabarok yang pertama hanya mendapatkan plafond pinjaman Rp. 2.000.000. Pada saat itu usahanya dapat dikategorikan lancar, pembayaran angsuran setiap harinya sesuai dengan kesepakatan di awal dan berlangsung selama 3,5 bulan, sehingga pihak bank dengan mudah memberikan tambahan plafond pembiayaan agar usahanya semakin berkembang. Plafond pinjaman kedua yang diterima sebesar Rp.3.000.000. Pada pengambilan kedua usaha dan pembayaran angsuran pembiayaannya dapat dikategorikan lancar, tetapi hal tersebut hanya berlangsung di bulan ke 1 dan 2. Selanjutnya, di bulan ke 3 pembayaran angsuran pembiayaan tidak sesuai dengan kesepakatan, pembayaran angsuran setiap harinya menurun atau bahkan tidak membayar sama sekali, dan harus diambil secara langsung oleh collector ke lokasi usaha nasabah. Pada saat collector menjemput angsuran pembiayaan nasabah, collector sekaligus memonitoring usaha nasabah, serta mencari tahu penyebab penurunan angsuran pembiayaannya. Setelah dilakukan monitoring, jam operasional usaha nasabah tidak sama dengan sebelumnya, selain itu jumlah dagangannya berkurang, sehingga prospek usahanya menurun. Oleh karena itu, pihak BPRS SPM Pamekasan juga melakukan pendekatan untuk mengetahui lebih dalam tentang usaha yang dijalaninya. Setelah melakukan penelusuran, nasabah A mengalami musibah dikarenakan cucunya sakit, sehingga sebagian

\footnotetext{
${ }^{33}$ Herman Darmawi, Manajemen Risiko, (Jakarta: Bumi Aksara, 2006), 34.

${ }^{34}$ Nur Rianto Al- Arif dan Yuke Rahmawati, Manajemen Risiko Perbankan Syari'ah, (Bandung: Pustaka Setia, 2018), 31.
} 
modalnya digunakaan untuk kebutuhan tersebut, dan ini akan mengganggu perkembangan usahanya. Maka dari itu, pihak BPRS SPM mencoba memberikan solusi dengan cara memberikan dana bantuan infaq dan shadaqah untuk keperluan pengobatan cucunya agar pendapatan usahanya tetap bisa digunakan sebagai modal di hari berikutnya, sehingga jumlah penjualan nasabah bisa kembali normal. Selain memberikan dana infaq dan shadaqah, pihak BPRS SPM Pamekasan juga tidak mengambil bagi hasil di bulan ke 3.

\section{Risk Control}

Pengendalian risiko dilakukan sebagai proses dalam mengendalikan risiko yang dapat menimbulkan kerugian bagi pihak bank. ${ }^{35}$ BPRS SPM Pamekasan melaksanakan pengendalian risiko dengan cara mengevaluasi risiko yang dialami oleh beberapa nasabah. Peningkatan kemampuan karyawan BPRS SPM juga sangat penting dilakukan, berkenaan dengan pembiayaan Tabarok yang penyalurannya tanpa menyerahkan agunakan, sehingga risiko yang akan diterima juga sangat tinggi.

Salah satu cara untuk mengevaluasi risiko yang dialami oleh nasabah, yaitu dengan melihat karakter calon nasabah, jika karakter nasabah tersebut angkuh, maka account officer harus mengetahui cara untuk mengendalikan karakter nasabah tersebut. Berbeda hal nya jika nasabah memiliki karakter yang baik, maka account officer juga harus mampu mengetahui cara untuk mengendalikannya.

Dalam mengendalikan risiko account officer harus mempunyai kesadaran bahwa pembiayaan Tabarok dapat menimbulkan risiko yang tinggi. Maka dari itu, penting sekali bagi account officer untuk berhati-hati dalam melaksanakan proses pengendalian risiko yang dialami oleh nasabah, karena saat terjadi kesalahan dalam prosesnya, pihak BPRS SPM juga akan mengalami kerugian.

\section{E. Risk Saving}

Dalam proses menyelamatankan risiko, pihak BPRS SPM akan melaksanakan beberapa cara saat pembiayaan mulai berpotensi akan mengalami permasalahan, yaitu:

1) Berkunjung ke lokasi usaha nasabah,

2) Jika nasabah sudah tidak berada di lokasi usahanya, maka pihak collector akan menghubungi nasabah, agar mengetahui penyebab nasabah tersebut tidak berjualan.

3) Ketika pihak collector menghubungi dan tidak ada jawaban dari nasabah, maka pihak collector akan berkunjung ke rumah nasabah tersebut untuk melakukan penagihan dan mencari tahu secara detail penyebab tidak berjualan dan terlambat membayar angsurannya.

4) Selama tiga hari nasabah tetap tidak melakukan transaksi ke BPRS SPM, maka collector akan melakukan pendekatan kepada nasabah.

5) Jika selama satu minggu tetap tidak melakukan pembayaran angsuran, maka collector akan melakukan koordinasi bersama account officer untuk menindaklanjuti hal tersebut dengan cara monitoring usaha nasabah, agar mengetahui lebih detail penyebab pembayaran angsuran yang tidak lancar.

6) Selama 2 minggu sekali, nasabah akan menerima pesan SMS Masking yang bertujuan untuk mengingatkan nasabah yang telah memasuki jatuh tempo atau telah melewati batas jatuh tempo pada pembiayaan Tabarok, agar nasabah tersebut melakukan pembayaran pembiayaan sesuai dengan kesepakatan bersama.

7) Ketika nasabah tetap tidak melakukan pembayaran angsuran selama 3 minggu, maka pihak BPRS SPM akan mengeluarkan surat pemberitahuan (SP) sebagai peringatan agar nasabah menyelesaikan tanggung jawab pembayaran angsurannya.

${ }^{35}$ Adiwarman A. Karim, Bank Islam: Analisis Fiqh dan Keuangan, (Jakarta: PT Raja Grafindo Prenada, 2013), 255. 
8) Setelah dikeluarkannya surat pemberitahuan (SP) tersebut, nasabah diharapkan kehadirannya untuk mendatangi BPRS SPM Pamekasan dan memusyawarahkan terkait usahanya agar bisa menyelesaikan tanggung jawab pembayaran angsurannya kepada pihak BPRS SPM.

9) Apabila nasabah masih mempunyai i'tikad baik, maka pihak BPRS SPM akan memberikan solusi dalam penyelesaian pembiayaan bermasalahnya, yaitu dengan cara restructuring.

Restructuring atau penataan kembali, penyelamatan pembiayaan bermasalah ini dilakukan untuk menambahkan dana, tetapi dengan syarat pembiayaan sebelumnya harus diselesaikan terlebih dahulu, setelah itu dana lainnya sebagai tambahan modal usahanya. ${ }^{36}$ Misalkan, nasabah dengan plafond pinjaman Rp. 2.000.000, tetapi setelah lebih dari 90 hari nasabah dapat diprediksi akan mengalami kemacetan dalam pembayaran angsurannya, hal ini karena usahanya mengalami penurunan omset yang diakibatkan oleh perubahan cuaca. Sedangkan sisa pembiayaan Tabarok yang harus dikembalikan sebesar Rp. 1.000.000, maka pihak BPRS SPM Pamekasan akan memberikan solusi dengan memberikan tambahan dana sebesar Rp. 1.500 .000 - Rp. 2.500.000. Dana tersebut digunakan untuk menutupi pembiayaan yang sebelumnya, kemudian sisa dana tersebut digunakan sebagai tambahan modal usahanya. Tetapi tidak semua nasabah yang mengalami pembiayaan bermasalah akan dilakukan tindakan restructuring, tergantung dari karakter masing-masing nasabah. Jika nasabah tersebut memiliki i'tikad yang baik untuk menyelesaikan pembiayaannya serta prospek usaha masih bisa dibantu, maka pihak BPRS SPM akan bersedia untuk memberikan bantuan kepada nasabah tersebut.

Dalam mengelola pembiayaan Tabarok di BPRS SPM sangat diperlukan beberapa strategi dan prinsip kehati-hatian dalam menangani pembiayaan baru, artinya pembiayaan yang akan bermasalah dan pembiayaan yang sudah dikategorikan sedang bermasalah sampai berpotensi bermasalah. Risiko pembiayaan dipengaruhi oleh beberapa faktor, yaitu faktor internal dan faktor eksternal. ${ }^{37}$ Pertama, faktor internal yaitu diakibatkan karena kurang maksimal dalam menerapkan prinsip kehati-hatian dalam penyaluran pembiayaan Tabarok, atau dapat juga diakibatkan oleh karakter karyawan. Kelalaian karyawan dalam menerapkan prinsip kehati-hatian ketika melakukan analisis calon nasabah pernah terjadi pada saat awal penyaluran pembiayaan Tabarok. Namun seiring dengan berjalannya waktu, masing-masing karyawan memiliki prinsip kehati-hatian sendiri yang disesuaikan dengan karakter nasabah agar tidak terjadi nasabah tidak melakukan kecurangan dalam memberikan informasi terkait usahnya dan terhindar dari penyalahgunaan dana pembiayaan Tabarok. Kedua, faktor eksternal dalam pembiayaan Tabarok diakibatkan karena penyimpangan (moral hazard) nasabah atau kelalaian dalam menjalankan usahanya, sehingga pendapatan nasabah mengalami penurunan yang nantinya akan berpengaruh terdapat pembayaran angsuran pembiayaan nasabah.

BPRS SPM tidak hanya melakukan penyelamatan risiko dengan melaksanakan restructuring, tetapi juga men-cover pembiayaan Tabarok dengan asuransi. Nasabah yang akan mengajukan dan telah menggunakan dana pembiayaan Tabarok tidak hanya mendapatkan dana secara utuh dan tanpa menyerahkan agunan, tetapi juga ter-cover asuransi, sehingga nasabah merasa aman dan nyaman dalam menggunakan pembiayaan Tabarok. Nasabah yang ter-cover asuransi yaitu berusia di bawah 60 tahun. Pihak BPRS SPM mengalokasikan dana untuk asuransi dan bekerjasama dengan lembaga asuransi untuk mencover objek pembiayaan yang dimiliki oleh nasabah. Hal tersebut merupakan salah satu cara untuk mengantisipasi terjadinya risiko di masa yang akan datang seperti kebakaran, gempa, angin puting beliung. Asuransi tersebut juga bisa digunakan untuk mengantisipasi nasabah

\footnotetext{
36 Kasmir, Dasar-dasar Perbankan, 149.

${ }^{37}$ Abbas Salim, Asuransi \& Manajemen Risiko (Jakarta: Rajawali Pers, 2012), 201.
} 
meninggal sebelum melunasi angsuran pembiayaan. Hal ini dilakukan untuk meminimalisir risiko dan sebagai salah satu cara untuk menyelamatkan pembiayaan bermasalah.

\section{Gambar 3.5 Siklus Karakter Risk Management Pembiayaan Tabarok di BPRS SPM Pamekasan}

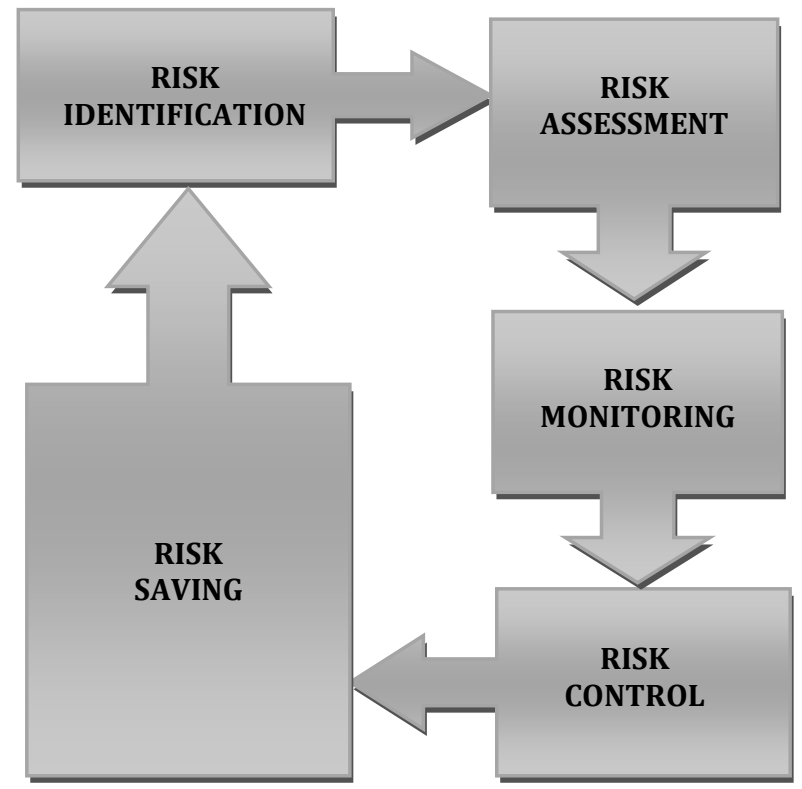

Berdasarkan penjelasan di atas dapat diketahui bahwa BPRS SPM Pamekasan menerapkan lima tahapan risk management, yaitu risk identification, risk assessment, risk monitoring, risk control, dan risk saving. Menurut teori, karakter manajemen risiko dalam operasional bank shariah terdapat empat tahapan yaitu, risk identification, risk assessment, risk monitoring, dan risk control. ${ }^{38}$ Sedangkan, implementasi manajemen risiko di BPRS SPM terdapat tahapan lagi dalam prosesnya yaitu risk saving. Risk saving dilaksanakan agar risiko pembiayaan Tabarok yang menggunakan akad muḍ̄arabah dapat terselamatkan dengan cara melakukan restructuring sesuai dengan risiko yang dihadapi oleh nasabah, sehingga pembiayaan Tabarok dapat mengalami perkembangan yang baik dan lebih bermanfaat sebagai pembiayaan produktif.

\section{PENUTUP}

Implementasi risk management pada pembiayaan Tabarok di BPRS SPM Pamekasan dilakukan melalui lima tahapan risk management, yaitu: risk identification, risk assessment, risk monitoring, risk control, dan risk saving. Berdasarkan teori, dalam operasional bank shariah terdapat empat tahapan karakter risk management yaitu, risk identification, risk assessment, risk monitoring, dan risk control. Sedangkan, implementasi manajemen risiko di BPRS SPM terdapat tahapan lagi dalam prosesnya yaitu risk saving. Risk saving dilaksanakan agar risiko pembiayaan Tabarok yang menggunakan akad muḍarabah dapat terselamatkan dengan cara melakukan restructuring sesuai dengan risiko yang dihadapi oleh nasabah, sehingga pembiayaan Tabarok dapat mengalami perkembangan yang baik dan lebih bermanfaat sebagai pembiayaan produktif. Berkaitan dengan kekurangan dalam penulisannya, penelitian ini perlu dikembangkan dan disempurnakan oleh peneliti selanjutnya, maka dari itu kritik dan saran dalam penelitian ini sangat diperlukan agar risk

38 Adiwarman A. Karim, Bank Islam: Analisis Fiqh dan Keuangan, 256. 
management bisa lebih sempurna serta dapat diterima oleh seluruh lembaga keuangan yang menerapkan dan mengaplikasikannya.

\section{DAFTAR PUSTAKA}

Al- Arif, Nur Rianto. Yuke Rahmawati. Manajemen Risiko Perbankan Syari'ah. Bandung: Pustaka Setia. 2018.

Ali, Masyhud. Manajemen Risiko: Strategi Perbankan dan Dunia Usaha Menghadapi Tantangan Globalisasi Bisnis. Jakarta: PT RajaGrafindo Persada. 2006.

Asiyah, Binti Nur. Manajemen Pembiayaan Bank Syariah. Yogyakarta: Kalimedia. 2015.

Capriani, Ni Wayan Wita. I Made Dana. "Pengaruh Risiko Kredit, Risiko Operasional, Risiko Likuiditas Terhadap Profitabilitas BPR di Kota Denpasar". E-Jurnal Manajemen Unud. Vol. 5. No. 3. 2016.

Creswell, John W. Research Design: Pendekatan Kualitatif, Kuantitatif, dan Mixed. Yogyakarta: Pustaka Pelajar. 2017.

Darmawi, Herman. Manajemen Risiko. Jakarta: Bumi Aksara. 2006.

Departemen Agama RI. Al- Qur'an dan Terjemahan Tajwid.

Dewi, Ni Made Indah Purnama. Ida Bagus Panji Sedana. "Efektivitas Manajemen Risiko dalam Mengendalikan Risiko Kredit di PT Bank Rakyat Indonesia”. E-Jurnal Manajemen Unud. Vol. 6. No. 8. 2014.

Fahmi, Irham. Manajemen Perbankan: Konvensional dan Syariah. Jakarta: Mitra Wacana Media. 2015.

Fatwa Dewan Syari'ah Nasional MUI, No: 07/DSN-MUI/IV/2000 tentang Pembiayaan Mudharabah (Qiradh).

Hanafi, Mamduh M. Manajemen Risiko. Yogyakarta: UPP STIM YKPN. 2016.

Ismail. Manajemen Perbankan: Dari Teori Menuju Aplikasi. Jakarta: PrenadaMedia Group. 2016.

Ismail. Perbankan Syariah. Jakarta: Kencana. 2011.

Jureid. "Manajemen Risiko Bank Islam (Penanganan Pembiayaan Bermasalah dalam Produk Pembiayaan pada PT Bank Muamalat Cabang Pembantu Panyabungan)". Jurnal Analytica Islamica. Vol. 5. No. 1, 2016.

Kasmir. Dasar-Dasar Perbankan. Jakarta: Rajawali Pers. 2014.

Karim, Adiwarman A. Bank Islam: Analisis Fiqh dan Keuangan. Jakarta: PT Raja Grafindo Prenada. 2013.

Muhammad. Manajemen Pembiayaan Bank Syari'ah. Yogyakarta: UPP AMP YKPN. 2006.

Nawawi, Ismail. Manajemen Perbankan Syariah. Jakarta: CV Dwi Putra Pustaka Jaya. 2014.

Otoritas Jasa Keuangan. Statistik Perbankan Syariah. Departemen Perizinan dan Informasi Perbankan. 2020.

Rudi. "Manajemen Risiko Bank Pengkreditan Rakyat dan Pengaruhnya Terhadap Non Performing Loan (Study Kasus BPR di Kota Tangerang Selatan)". Jurnal Sekuritas Manajemen Keuangan. Vol. 1. No. 1. 2017.

Salim, Abbas. Asuransi \& Manajemen Risiko. Jakarta: Rajawali Pers. 2012.

Sukamdiyo. Manajemen Koperasi. Jakarta: Erlangga. 1996.

Susilo, Edi. "Analisis Perbandingn Penerapan Manajemen Risiko Pembiayaan Lembaga Keuangan Mikro Syariah Studi Kasus di BMT Beringharjo Yogyakarta dan BPRS 
Implementasi Risk Management pada Pembiayaan Tabarok (Studi Kasus di BPRS SPM Pamekasan)

Madina Mandiri Sejahtera Yogyakarta". Jurnal Ekonomi Bisnis \& Kewirausahaan. Vol. 4. No. 2. 2014.

Sutedi, Adrian. Perbankan Syariah Tinjauan dan Beberapa Segi Hukum. Bogor: Ghalia Indonesia. 2009. 